\title{
Towards a comparative study of the structure of sentiment among the Austronesians ${ }^{1}$
}

\author{
James J. Fox
}

\section{Introduction}

The chapters in this volume offer a contribution to the comparative study of Austronesian conceptions of thought and emotions. These papers vary in their approach, their focus and in the particular societies they examine, but they also point to a variety of similar cultural patterns. While their diversity suggests different avenues for exploration of a complex subject, their common features combine to highlight critical areas of research.

As a collection, these papers are also intended to focus-or, more exactly, refocus-attention on the study of Austronesian ideas of thought and emotions for which there is already an impressive literature and an array of valuable research. In introducing these papers, the first task is to recognise this previous research and to relate elements within this literature to the

\footnotetext{
1 Rodney Needham, my D.Phil. supervisor at Oxford, came to prominence with the publication of his book Structure and Sentiment (1962). Years later, after the publication of his book Belief, Language and Experience (1972), he set to work on a book he said would be entitled The Structure of Sentiment. His intent was, I believe, to examine the structural patterning of categories of thought and the emotions, but he never completed this book and never revealed its contents. Without any certain idea of the substance of this work, I have chosen to insinuate his title into this introduction as a personal link to the comparative effort I imagine he had hoped to provoke.
} 
chapters in this volume. The foundation for the study of Austronesian thought and emotions has been well laid and, therefore, to move forward, in a comparative framework, it is essential to recognise and acknowledge contributions of potential significance.

\section{Selecting a starting point}

Contrary to the assertion that there has been relatively little research done on the ethnography of Austronesian thought and emotions, it is possible to point to a considerable and remarkably varied literature on thinking and feeling among Austronesian-speaking populations. This literature combines substantial studies in anthropology and linguistics that offer a valuable starting point from which to consider the contributions offered in this volume.

A useful starting point to consider the trajectories of these previous studies and the particular legacies they bequeathed to the field is the remarkable confluence of publications - an exceptional burst of original papers on Austronesian thought and emotions - that appeared at virtually the same time in the early 1980s. Seen in retrospect, these varied papers offer a wealth of observations and insights for comparative consideration.

The first of these publications is the pioneering volume Culture Theory: Essays on mind, self and emotion, edited by Richard A. Shweder and Robert A. LeVine, which was published in 1984, comprising the papers of a Social Science Research Council conference held in 1981. Richard Shweder, in his 'Preview', defined the most general goal of the volume as presenting 'a broad-gauged and accessible discussion of theories of culture' in relation to 'research issues in the development of mind, self and emotion' (1984: 1).

The volume certainly achieved this goal. It was a genuinely seminal work that offered a substantial critique of previous behavioural-oriented research and provided a rich diversity of views setting out various directions- not all compatible-for future research. Significantly, among the contributions in this volume were three important papers by key researchers who focused on their Austronesian ethnographies. Remarkably, each of these contributors traverses similar grounds in separate ways.

Robert Levy was the first of these Austronesianist contributors. Threading his way between supporters and denigrators of the study of the emotions, Levy argues for 'a general person-oriented ethnography' attuned to the 
features of each community (Levy 1984: 216). Although wideranging in its general discussion, the essay repeatedly and specifically draws on Levy's crucial fieldwork in Tahiti to illustrate its general argument. In distinguishing between 'hypocognised' feelings—nonspecific, general 'underschematised emotional domains'-and 'hypercognised' classifications of feelings, he singles out, for Tahiti, the categories of anger, shame and fear as 'hypercognised'. He relates this distinction to modes of control-feelings controlled 'by not being known', in contrast to feeling known in obsessive detail. Thus, hypercognition 'involves a kind of shaping, selecting, and standardizing, a familiar function of cultural symbols and forms' (Levy 1984: 227).

Another of the contributors was Clifford Geertz. In his essay, 'From the native's point of view', Geertz argues that the 'concept of person' is 'an excellent vehicle ... to go about poking into another people's turn of mind'. He describes the 'intellectual vitality' of Javanese labourers to theorise over 'relations between reason and passion' couched in a contrast between 'inside' and 'outside':

$[\mathrm{T}]$ wo sets of phenomena-inward feelings and outward actions ... regarded not as functions of one another but as independent realms of being in no part to be put in proper order independently. (Geertz 1984: 126-7)

He compares these Javanese conceptions with what he encountered in Bali: 'a bifurcate conception of the self ... an inner world of stilled emotion and an outer world of shaped behaviour ... a persistent and systematic attempt to stylize all aspects of personal expression' (Geertz 1984: 128). In this context, Geertz retranslates the Balinese term lek, normally translated as 'shame', as 'stage fright': 'the fear that, for want of skill or self-control, or perhaps by mere accident, an aesthetic will not be maintained, that the actor will show through his part' (1984: 128-30).

The third of these three distinguished Austronesian contributors to the volume was Michelle Rosaldo, whose ethnographic focus was concentrated on the Ilongot of Luzon in the Philippines. She notes that her comments are further reflections on her monograph Knowledge and Passion (1980). Her essay is no less wideranging or challenging in its analysis than the others in the volume. She argues for an intimate interpenetration of thought and affect: 'feeling is forever given shape through thought and that thought is laden with emotional meaning' (Rosaldo 1984: 143). At the core of the Ilongot person is a self, identified with the heart, who is both inwardly hidden and outwardly active: 
Thus Ilongots see the rinawa or (heart) [*nyawa] as something that responds and acts within the world but also claim that actions of the 'heart' are often hidden, inexplicable, opaque, autonomous. (Rosaldo 1984: 145)

Intriguingly, she touches on a similar array of emotions as Levy and Geertz—shame, fear and anger:

Ilongots are concerned primarily not to protect but rather to assert the potency of equal, 'angry' hearts in everyday affairs. Thus, Ilongot 'shame' is not a constant socializer of inherently asocial souls but an emotion felt when 'sameness' and sociality are undermined by confrontations that involve such things as inequality and strangeness. (Rosaldo 1984: 149)

She goes on to call for a cross-cultural study not of 'shame', but of the diversity of 'shames'.

Each of these contributors was able to give ethnographic elaboration to their papers: Levy, in his monograph Tahitians: Mind and experience in the Society Islands (1973); Geertz, particularly in his study Person, Time and Conduct in Bali (1966); and Rosaldo, in her masterful monograph, Knowledge and Passion: Ilongot notions of self and social life (1980). This monograph is perhaps the most extensive, subtle and insightful exploration of the thought and emotions of any Austronesian-speaking population - a model of its kind that rewards careful consideration. ${ }^{2}$

The second volume for consideration is the special issue of Ethos that appeared in 1983 organised by Robert Levy on 'Self and Emotion', a collection that refers to the Culture Theory volume, which was, at the time, in press. Apart from Levy's introduction, this Ethos collection contains a further key Ilongot essay by Michelle Rosaldo, on 'The shame of headhunters and the autonomy of self', and another important essay, by Ward Keeler, on 'Shame and stage fright in Java', which draws on both Clifford and Hildred Geertz's work on Bali and Java.

In his introduction, Levy puts forward an argument for Rosaldo's ideas about the cultural patterning of the emotions in different societies while rejecting the stereotyping of an entire society by particular emotional valency. In her essay, Rosaldo pursues her ethnographic reflections specifically on the Ilongot conceptions of shame (bétang), providing

2 Here I should declare a personal involvement that undoubtedly colours my judgement: Shelly Rosaldo was my first PhD student at Harvard. Her energy, talent and intelligence were extraordinary and her tragic death, while doing fieldwork among the Ifugao, was an incalculable loss. 
a detailed, complex and marvellously nuanced examination of shame in relation to 'fear' (kayub), as well as 'humility, respect and honour' (tu'ngan): shame as a stimulus for action and as a prod for emulation as well as a constraint on behaviour. Shame creates a 'heaviness' that controls anger, but gives rise to a 'lightness' when that anger is released.

Following the general theme of the volume, Keeler discusses the polarities of shame (isin) and fear (wedi) for the Javanese. For a child, the acquisition of the proper awareness of the sentiment of shame is crucial to learning to negotiate social interaction. Showing that one knows shame (ngerti isin) demonstrates, especially to outsiders, that one is conscious of one's position in society. Without this awareness, social situations can cause fear, but fear is more than an emotional relationship to the strangers; fear is also a form of respect towards one's elders. As different as these polarities of fear and shame are among the Ilongot and the Javanese, they gravitate in a similar dimension.

The third publication in this consideration is Person, Self, and Experience: Exploring Pacific ethnopsychologies, edited by Geoffrey M. White and John Kirkpatrick (1985), published only a year after the Shweder and LeVine volume. This book grew out of a symposium held in 1982 at the annual meetings of the Association of Social Anthropology in Oceania. In it, many of the same issues raised in the Culture Theory and Ethos volumes were further explored by various researchers in relation to the specific Austronesian societies they had studied. It is instructive, therefore, to point to these same notions - the bodily locus of thought and emotion and the highlighting of specific feelings - in the succession of papers in the volume.

In the first paper of the volume, Catherine Lutz summarises key aspects of her research on Ifaluk, which she later elaborated on in her monograph Unnatural Emotions (1988). One aspect of the analysis of emotions, which she emphasises, is the crucial relationship of the person to the body:

On Ifaluk, as elsewhere, the body's structure and well-being are seen to be involved in an inseparable and systematic way with psychosocial well-being ... 'the emotional mind' of Ifaluk ethnopsychology is solidly embedded in moral and social life ... and in the physical body ... Traditionally, all thought/emotions (nunuwan) and 'will/emotion/desire' (tip-) were believed to be experienced in the 'gut' ... The 'gut', as the traditional seat of thought, feeling, and will, is seen in a very real sense as the link between mind and body or, more accurately, as the core of the self in both its physical and mental functioning. (Lutz 1985: 52-3) 
Geoffrey White, in his essay on the ethnopsychology of A'ara on Santa Isabel in the Solomon Islands, reinforces Lutz's insistence on the importance of the image of the body in the expression of sentiment: 'The human body is a potent symbol of personal well-being. A'ara speakers extend certain core concepts of bodily experience to the domain of social experience' (1985: 333).

White also raises the issue of the complexities of analysis required in the consideration of the relations between persons and spirits-a common feature of the social life in many Austronesian societies. Peter Black, writing on the population of the island of Tobi in Micronesia, takes up this issue in regard to fear prompted by ghosts, anger and shame. Among the Tobi population, intense shame leads to the expression of anger, which is regarded as 'acting like ghosts' (Black 1985: 282).

Like other contributors, John Kirkpatrick argues that shame (hakäika) 'deserves a prominent place in an account of Marquesans' interactions and experience', but such hakäika can only be understood in 'the matrix of cultural knowledge in which it is embedded' (1985: 83). He goes on to examine hakäika in relation to two other prominent Marquesan terms, ka'oha ('concern' towards others) and keitani ('envy' by another towards oneself). He quotes an informant's description of hakäika that gives this emotion a locus and intensity: 'The guts tremble; one fears; one doesn't want to go [i.e. continue] ... the belly thinks' (Kirkpatrick 1985: 89).

Similarly, Karen Ito, in her essay on Hawaiian affective bonds, argues that the 'Hawaiian concept of self is grounded in affective social relations' and 'these social relations are not confined to humans but include the spiritual and natural worlds as well' (1985: 301). She goes on, however, to give a central locus to these affective sentiments:

The importance of affect for Hawaiian social relations and self concept is most clearly demonstrated in the concept of na'au which literally means one's innards and more generally refers to one's heart, mind or affections. One's na'u is the seat of one's intelligence, feeling and sincerity. It is important that a person act 'with heart' sincerely, affectionately, thoughtfully, and without reservation in the extension of self. (Ito 1985: 301)

In contrast to the various analyses of specific emotions, Eleanor Gerber's paper on the examination of 44 named Samoan emotions-grouped in four clusters by informants' judgements on relative similarity-offered, at the time, another methodological approach for an ethnographic 
assessment of affect that stimulated further research by Karl Heider, particularly for the Minangkabau (1981, 2011). The study of 'domains of emotion', their activation as strong affect and their culturally contextual similarities provided another ethnographic dimension for comparison among Austronesian-speaking populations.

In retrospect, one can recognise in these dozen or so papers-all written at roughly the same time-a remarkable configuration of observations and insights that provide an exceptional perspective for the comparative consideration of Austronesian thought and emotions. Following Levy, it may well be that, among Austronesian populations, certain emotions tend to be 'hypercognitised' - 'shame', 'fear' and 'anger' among them. It is also seemingly significant that there appears to be a locus for emotions among Austronesians in what is variously called the 'heart', 'gut' or 'belly'. Also significant is the repeated observation that thinking and feeling are intertwined within the body and that key emotions are frequently elaborated in metaphoric bodily expressions. Equally important is the critical observation that each of a culture's key emotions has multiple, subtle dimensions and understanding derives from the careful consideration of the emotions in relation to each other.

In this context, it is valuable to consider Karl Heider's two studies, Landscapes of Emotion: Mapping three cultures of emotion in Indonesia (1981) and The Cultural Context of Emotion: Folk psychology in West Sumatra (2011), both of which are interesting experiments in analysis. His study-particularly his first study-is focused on the Minangkabau of West Sumatra, although he also considers Indonesian as spoken by Minangkabau and Javanese. Based on a combination of questionnaires and work with different groups of informants, this study examines a lexicon of 200 words for emotion and attempts to map connections among them. The result is what Heider describes as a 'cognitive map of emotion words' (1981: 40)—a global landscape of emotional relations primarily in Minangkabau. As a Malayic language, Minangkabau is closely related to Indonesian (and Malay). Consequently, although minor differences emerge, it is difficult to disentangle these differences from within the methodology and to discern their significance.

Heider divides this lexical landscape into 44 tighter clusters of emotional relations and devotes the second half of his Landscapes volume to examining these separate clusters, each primed to particular terms'surprise' (M: takajuik; I: terkejut), 'happy' (M: sanang; I: gembira), 'desire' 
(M: suko; I: ingin) —of high saliency ('prototypicality') as defined by his informants, which extend from a core of related terms to a range of other terms. The value of this analysis is its emphasis on the dynamics of the formation of emotions, considering the way in which particular emotions form 'way stations' leading to other emotions.

Heider's second book builds on his earlier work but delves much more deeply into the ethnographic sense of the particular emotion clusters outlined in the first volume.

\section{The possibilities of comparison: A relational analysis of shame and fear}

The accumulation of ethnographic accounts of Austronesian thought and emotion provides marvellous insights but does not, of itself, provide a comparative perspective. The question is whether such a comparative perspective is possible and, if it is possible, how it can possibly be achieved. Is it possible, for example, to compare Gerber's general findings on Samoa with Heider's findings on the Minangkabau and consider how particular emotions relate to one another within their wider cultural domains? In this regard, I would like to consider the emotions of shame and fear (and anger), already identified variously by many ethnographers of different Austronesian societies, as hypercognitised emotions or as emotions of a high saliency.

Shame, in particular, has significant valency among Austronesians. There is hardly an extended ethnography of an Austronesian people that does not touch on, and often elaborate on, the social importance of shame. More than anger or fear, shame is a learned emotion. Its circumstances, causes and conditions vary from society to society (and indeed within a society), and all of this needs to be taught from an early age. Often it would seem that the learning of shame sets the basis or prerequisite for further emotional learning. Hollan and Wellenkamp, for example, in their ethnography of the Torajan life cycle, The Thread of Life (1996), devote considerable attention to the development of shame, which, in the case of the Torajans, relates particularly and initially to sexual conduct. Hollan and Wellenkamp set out this development clearly: 'Soon after children develop a sense of shame (siri') ... they begin to feel modest in front of members of the opposite sex, especially opposite-sex siblings' (1996: 56). As they go on to explain: 
Although it is considered pointless to teach or discipline children before they are capable of experiencing shame and of 'hearing' their parents' words of advice $\ldots$ once children have attained such capacities, parents are thought to be responsible for providing them with proper instruction. (Hollan and Wellenkamp 1996: 137-8)

In the words of one Torajan informant: 'Once we know shame, we must be taught by our father and our mother ... As long as one is human, one must have shame. But parents add to it' (Hollan and Wellenkamp 1996: 135). Eventually, a range of other complex emotional conduct is inculcated on this initial foundation. Initially, as Hollan and Wellenkamp point out, parents can only rely on 'frightening' or 'shaming' children to control them. Thus, shame and fear are linked and learned at an early age.

Of other ethnographers, Keeler is perhaps the most explicit in linking shame/embarrassment (isin) with fear (wedi) among the Javanese, although, in fact, this only restates Hildred Geertz's exposition on the socialisation of Javanese emotions. As she writes:

Javanese children are taught how to be wedi and isin; they are praised for being wedi to their elders and $i s i n$ to their betters ... They learn wedi first ... [and] As they grow older isin is taught to them. (Geertz 1959: 233)

Rosaldo is equally explicit in her description of the core emotions taught to Ilongot children. In her discussion of early development of knowledge, she writes:

[O]bedience to the demands of another grows from 'fear' or kayub, and from bètang, a word whose sense includes aspects of the English 'respect', 'embarrassment' and 'shame' ... 'Fear' and 'shame' are understood by adults as the condition of obedience. (Rosaldo 1980: 70)

Lutz provides an extended and nuanced discussion of the relationship between the key emotions of shame/embarrassment ( $m a$ ), fear/ anxiety (metagu) and compassion/love/sadness (fago) among the Ifaluk. The Ifaluk ideal is to be a 'gentle', 'calm and quiet' person and not to be 'hot-tempered'. Feelings of fago, ma and metagu are the means by which a person is able to be such a calm person (Lutz 1988: 176-90).

Among the Marquesan informants, according to Kirkpatrick, this relationship is direct: 'in shame, the belly trembles in fear' (1985: 89). Among the Rotenese in eastern Indonesia (Fox, Chapter 5, this volume), rituals require the pairing of terms, including all key emotions. As such, the 
term for 'shame' (mae) pairs with the term for 'fear' (bi) so that, at critical junctions of ritual uncertainty, the formal injunction to participants is boso bi ma boso mae: 'do not be fearful, do not be ashamed'. Valerio Valeri describes this connection between fear and shame among the Huaulu of Ceram in terms of its converse: 'Being unashamed in the eyes of the others may occur just like being unafraid' (2000: 404).

Casting the examination of emotions in a wider context for Samoa, Gerber locates the emotions of shame (mäsiasi) and fear (fefe) in close relationship to one another and in the same cluster (Cluster 4) with emotions of shyness (matamuli), worry (popole) and hurt (mafatia). Anger and jealousy are in a separate cluster (Gerber 1985: 140). Interestingly, Lutz, who has carried out a cluster analysis of Ifaluk emotions, also locates shame/embarrassment $(m a)$ in the same cluster (Cluster 2) with fear/anxiety (metagu) - a cluster that also includes terms for discomfort (lugumet), fright (rus) and disappointment (bobo), which are all emotions of negative valence (1982: 116). Similarly, Heider, in his examination of the relationship among named Minangkabau emotions, draws the connection between shame (malu, segan) and fear (takut) more emphatically, arguing for a "close association of "fear" and "shame" (2011: 142), and going so far as to assign the gloss 'shame' as another translation for the word takut. In his second volume, The Cultural Context of Emotion, Heider provides an extended and nuanced discussion, in succession, of these two terms (2011: 127-46).

Certainly, an impressive array of ethnographers has separately but cogently pointed to a significant relationship between shame and fear among Austronesian populations-from Sumatra and Java through eastern Indonesia to the Pacific. This in itself is of interest but perhaps, more importantly, such observations suggest that, to reach an understanding of Austronesian emotions, they have to be approached not individually as separate sentiments but relationally one to another within a wider context.

\section{Linguistic research on Austronesian thought and emotions: Various starting points}

Linguistic approaches to the study of Austronesian thought and emotion are certainly as various as those in anthropology. Often of a comparative focus, these studies frequently differ in their scope and direction. One particularly productive starting point for linguistic comparisons 
is the paper by James Matisoff 'Hearts and minds in South-East Asian languages and English' (1986). Directed to the comparative examination of various languages in South-East Asia-mainly belonging to the SinoTibetan language family (Burmese, Lahu, Jingpho), but also ThaiMatisoff calls attention to what he describes as 'psycho-collocations': the lexico-semantic designation of mental activities and personal qualities by metaphoric associations with bodily parts. In his scheme, a 'psycho-term' (psycho) is combined with a 'psycho-mate' (mate) to produce a 'psychocollocation' (psi-collocation). He illustrates this with two simple examples:

$\begin{array}{lllll}\begin{array}{l}\text { Language } \\ \text { Lahu }\end{array} & \begin{array}{l}\text { Phrase } \\ n i-m a-l i ̀\end{array} & \begin{array}{l}\text { Psycho } \\ \text { 'heart' } \\ \text { Mate }\end{array} & \begin{array}{l}\text { Mate } \\ \text { 'ruin' }\end{array} & \begin{array}{l}\text { Psycho-collocation } \\ \text { 'be depressed' }\end{array} \\ \text { Thai } & \text { wáj caj } & \text { 'keep' } & \text { 'heart' } & \text { 'trust in' }\end{array}$

While such psycho-collocations may be universal in languages, they differ significantly among languages, although similar general patterning may occur within related groups of languages. Certainly, Matisoffs observations are relevant to Austronesian languages. He has given a focus to what has been reported on and described by linguists, anthropologists and especially dictionary compilers.

For comparative purposes, it is useful to begin with a discussion of similar psycho-collocations among Austronesian-language speakers in Taiwan. In a valuable short paper (2002), Shuanfan Huang has provided excellent examples of such psycho-collocations among the Tsou. A key element of his argument is that the Tsou language possesses no means of nominalising emotional concepts: 'emotion concepts must be realized syntactically as verbs and can never be nominalized' (Huang 2002: 171-2). Hence, Tsou does not and cannot exploit what Lakoff and Johnson (1980) call 'ontological metaphors'. Although perhaps not as pronounced as in Tsou, this is a tendency evident in other Austronesian languages as well.

Instead, in Tsou, emotions and processes of thought are expressed in relation to the body. "The body part most intimately associated with cognition (thinking or intending) or feeling in Tsou is koyu "ear", the seat of Tsou emotion and mentation' (Huang 2002: 172). Various examples of this are the following:

- micu naéo co koyu-taini: 'she has been sad' (lit.: his/her ear has been sad)

- os'o cong'eneni koyo 'e: 'I feel distressed about my children' (lit.: my ear aches for my children) 
- ci os'ko cohivi co koyu-'u? 'How do you know what I think?' (lit.: how do you know my ear?)

- ci na'on kuici koyu? 'Why are you in such a bad mood?' (lit.: why are your ears so bad?)

From his linguistic analysis, Huang goes on to suggest that 'grammatical models involving prefixation in Tsou make it far more sensitive to the co-presence of emotions and behaviour responses at the expense of physiological effects in emotional experience' (2002: 182).

Indonesian (Malay) provides an extensive array of recognisable psychocollocations. As is common among western Austronesian populations, here, the liver (in Indonesian: hati; Proto-Malayo-Polynesian: ${ }^{*}$ qatay) provides the basis for a significant number of psycho-collocations. Just a few of these psycho-collocations (from Echols and Shadily 1992: 206-7), of which there are many, are sufficiently illustrative:

$\begin{array}{ll}\text { hati bejar } & \text { 'courageous, encouraged' } \\ \text { hati bercagak } & \text { 'insincere' } \\ \text { hati berkarat } & \text { 'corrupted' } \\ \text { hati buntu } & \text { 'afraid, uneasy' } \\ \text { hati beku } & \text { 'cold-hearted, unhappy' } \\ \text { hati kecut } & \text { 'timid' } \\ \text { berhati berjantung } & \text { 'to be sensitive, compassionate' } \\ \text { berhati dendam } & \text { 'to be revengeful' } \\ \text { berhati-hati } & \text { 'to be careful' } \\ \text { berhati rawan } & \text { 'to be depressed, melancholy' } \\ \text { berhati tungau } & \text { 'to be cowardly' } \\ \text { berhati walang } & \text { 'to be concerned, anxious' }\end{array}$

This list offers an illustration of the use of hati as a marker of emotions in Malay and Indonesian. Linguist Cliff Goddard has written far more extensively on the use of hati as a 'key word in the Malay vocabulary of emotion' (2001: 167-95). His study highlights the extraordinary range and nuanced usage of this body term (see also Goddard 1996).

As a Malayic language, Iban shows many similarities to Indonesian (Malay). Clifford Sather, in his contribution to this volume (Chapter 3), lists a variety of Iban psycho-collocations that are based on the liver/heart (ati) as 'the principal seat of sentient awareness'. Among the Iban psychocollocations he cites are the following: 


$\begin{array}{ll}\text { gaga ati } & \text { 'happy' } \\ \text { pengerindu' ati } & \text { 'glad' } \\ \text { tusah ati } & \text { 'sad' } \\ \text { sinu' ati } & \text { 'pity' } \\ \text { penakut ati } & \text { 'frightened' } \\ \text { pengerawan ati } & \text { 'nervous, fearful' } \\ \text { pengirau ati } & \text { 'worried, anxious' } \\ \text { pemerani ati } & \text { 'courageous' } \\ \text { tembu' ati } & \text { 'contented' } \\ \text { penaluk ati } & \text { 'obedient' } \\ \text { pengangkun ati } & \text { 'steadfast, loyal' } \\ \text { chemuru ati } & \text { 'jealous' } \\ \text { pengaru' ati } & \text { 'suspicious' } \\ \text { bebulu ati } & \text { 'ill-natured' } \\ \text { begedi' ati } & \text { 'hate' }\end{array}$

Recognising the relationship with Malay, Sather goes on to cite various Iban expressions that share a close resemblance to their Malay equivalent. Thus, for example, he notes:

ambil hati (fetch + heart) in Malay and ngambi' ati (fetch + heart) in Iban have roughly the same meaning: 'to attract' or 'win the affections of'. Similarly, bakar hati (burn + heart) in Malay and panas ati (hot + heart) in Iban both mean 'hot-tempered'; busok hati (rotten + heart) in Malay and jai ati (bad + heart) in Iban both mean 'quick to take offence', 'illnatured'; and sakit hati (sick + heart) in Malay and pedis ati (hurt + heart) in Iban both mean 'annoyed', 'angry'.

He also notes where similarly constructed idiomatic expressions differ: 'besar hati (big + heart) in Malay has a slightly different meaning to besai hati (big + heart) in Iban'. Finally, but equally importantly, he notes where there appear to be no equivalences:

In Iban, there are no precise counterparts of the Malay kecil hati (small + heart) or of puteh hati (white + heart), while there are no apparent counterparts in Malay of the Iban expressions pengaru' ati (scratchy + heart), bebulu ati (to have hair + heart) or ensiban ati (splinter/thorn in the flesh + heart).

In identifying both the metaphoric similarities and the differences in these expressions of emotions between Malay and Iban, Sather also points to other bodily loci for the expression of emotions-particularly 
the 'gall bladder' (empedu; Proto-Malayo-Polynesian: qapeju) for 'shame' and the 'bones' (tulang) for feelings of strength or weakness. All of these emotions arise and emanate from within (di dalam).

Michelle Rosaldo concludes her Ilongot study, Knowledge and Passion, with an extended glossary (1980: 236-57) of the key terms she discusses in her ethnography. Under each of some 80 key terms, she provides a number of Ilongot sample sentences 'culled from texts, lexical interviews and notes on conversations' (Rosaldo 1980: 236). Her translations of these sentences are intended to give 'a sense of the lively and often "literal" ways that apparent "metaphors" tend to be seen' (Rosaldo 1980: 236). Among these key terms are a host of expressions for specific emotions that show clearly their basis as psycho-collocations.

For the Ilongot, rinawa, which Rosaldo glosses as 'heart', is the primary bodily focus of the emotions. (It is a reflex of the term nyawa, which more generally, in other Austronesian languages, is associated with 'breath' or 'spirit' and serves as another common psychosomatic linguistic operator for the expression of cognitive and emotional states. See Sather, Chapter 3, this volume.) In her glossary, Rosaldo gives a plethora of usages of this rinawa for the different expression of sentiments. As she explains, rinawa can be used verbally to mean 'like, want'. Here are a variety of the uses of rinawa in a selection of different sample sentences forming psychocollocations based on various verbal 'mates':

rinawa ('to will, want, to take heart')

$\mathrm{Nu}$ 'away rinawa mesigalan ma tu'u: 'A person without a heart gets thin.'

Nan'irinaway de: 'Their hearts are joined, they are in love.'

'aleng ('to be bored, weakened, sullen, dull')

$\mathrm{Nu}$ si ligetka 'un'a' aleng ta rinawan: 'If you are angry, your heart grows weak and dull.'

dikrat ('to be startled, made to jump, be distressed')

Dimikrat ma rinawak 'eta'gi kimeyeb: 'My heart was startled and rose with sudden distress.'

keтnи ('to be disappointed')

Kimemnuy ma rinawak: 'My heart was disappointed, saddened.'

ngalemken ('to tense, clutch, be angry')

'Engngalemkem ma rinawak nu meligetanak: 'My heart clutches with anger.' 
ruyuk ('to lengthen, be long, be happy')

'Awana 'unsipēka nu 'ed mangruyuk ma rinawan: 'You won't be happy, if our heart does not lengthen.'

As one moves eastward, the bodily focus for thought and emotion shifts towards a more general inner organ of the body, which is variously identified as 'inside', 'inner core', 'heart' or even sometimes 'belly' or 'gut'.

For Rotenese, this organ is referred to as the dale(k) (lit.: 'the inside') and, as such, it serves as the linguistic basis for a range of sentiments, a few of which are illustrative of this psycho-collocation (for an extended discussion, see Fox, Chapter 5, this volume):

dale malole: 'good-hearted, kind'

dale maloak: 'open, generous'

dale hedi: 'sad, sick at heart'

For Tetun speakers on Timor, this organ of thought and feeling is referred to by a cognate term, laran, which means 'inside' and is implicated in similar psycho-collocations. The following examples (cited by Grimes, Chapter 6, this volume) closely parallel those of the Rotenese:

nia laran diak: 'he is good-hearted, kind' nia laran maluka: 'he is open, generous, helpful' nia laran moras: 'he is offended, sickened'

Although there are notable similarities in the bodily expression of some emotional idioms in Rotenese and Tetun, the differences between these closely related languages are equally pertinent. Tetun directs the expression of emotions to a wider array of body parts than Rotenese, which relies more heavily on expressions based on 'inside' (dale) and 'stomach/belly' (tei). Thus, for example, as Grimes notes, in Tetun, 'anger' is associated with 'breath' or 'life force' (nawan), as in the expression nia nawan badak: 'he is quick to get angry'. Among the Rotenese, anger is conceived as a 'storm' that sweeps over a person, but a person inclined to ill temper and anger is described as dale nasa-meluk: 'bitter-hearted'. For the Tetun, 'selfishness' is located in the 'liver' (ate), as indicated by Grimes:

ema ne'e, ate kabahat: 'this person is very selfish/unsharing/stingy'

eme ne'e, ate fa'ek: 'this person is self-centred' 
For the Rotenese, a similar attribution is associated with the paired terms 'inside/heart'//'stomach/belly' (dale//tei); a selfish person is someone who only follows 'the dale's wish and the te'is desire' (dale hi ma tei nauk).

For the Buli of Halmahera, whose language is classified as belonging to the South Halmahera-West New Guinea subgroup of Austronesian, a similar body organ is identified as the ulo, which is glossed as 'the inner core, feeling, heart, consciousness'. Bubandt, writing of the Buli (2015: 125), provides a range of usages of this term 'to express a wide range of emotional and cognitive states':

uló loló: 'to wish for, to like, to have in the inner core'

uló ya senga: 'to be happy'

uló ya kangelá: 'to be troubled, sad'

uló ya amici: 'to be jealous, envious'

uló ya mafia: 'to be a good person'

uló ya mafia: 'to be a bad person, to have a bad inner core'

uló ya neto: 'to remember'

uló ya lal: 'to be undecided, to have many inner cores'

For the Dobu, this bodily inner core is referred to as nua, a term glossed as 'mind'. Dozens of compound expressions for thought and emotion rely on nua to create the appropriate psycho-collocation. Susanne Kuehling (Chapter 7, this volume) cites a variety of these expressions:

nua-mwauta: 'descending, to be humble'

nua-tue: 'climbing up, to be boastful'

nua-mwau: 'heavy, to be worried'

nua-siwalowa: 'calm and quiet, to be at peace'

nua-'iyowana: 'wandering aimlessly, to be confused'

Malinowski, in his classic study, The Argonauts of the Western Pacific (1922), translated the term nanola as 'mind' among the Trobrianders and, following his informants' comments, identified this organ with the larynx, but he went on to explain that all knowledge, especially magical formulae, resides in the belly and from there rises to the mind. Whereas this understanding represents Trobriand conceptions, the term nanola (root: nano) is in fact a reflex of the Proto-Oceanic (POc) *lalo and Proto-Malayo-Polynesian (PMP) *dalem, meaning 'inside' (see Osmond 2016: 523-33). Following Malinowski's work, Gunter Senft carried out a systematic examination of terms for the body and their use in the expression of thought and emotions (1998). (His Appendix A, 'Kilivila body-part terms', is particularly useful: Senft 1998: 94-103.) Of more 
than 50 such idiomatic expressions, a majority rely on the root nano(translated as 'larynx'), although key expressions also refer to the body (vovo-) as a whole, the head (daha-) and the belly (lopo-) (Senft 1988: 77).

Senft quotes one of his informants whose comments replicate what Malinowski's informants told him: 'If I whisper magic, the magical formulae will go from my lopo to my nano' (1998: 89). A few of the many psycho-collocations based on nano- that encompass a range of emotions and cognitive states are expressions such as:

i-polu nanom: 'it makes you jealous' (boils the mind)

i-kaikai nanosi: 'it irritates them' (it 'lightens' the mind)

i-mwau nano-gu: 'I am sad' (my mind is heavy)

bi-manum nanomi: 'you won't be angry' (your minds will be soft)

i-taki nanola: 's/he is obsessed'

i-yogagi-si: 'it upsets him/her' (it spoils him/her)

Although not all Austronesian emotions or cognition are expressed through psycho-collocations, it is impossible to consider the expression of such personalised processes without reference to these linguistic forms. Psycho-collocations and body metaphors may well constitute linguistic universals; the expression of these in relation to different body parts-ear, liver, heart, head, inside, belly, larynx — among Austronesian speakers is of comparative interest.

In the fifth volume of The Lexicon of Proto Oceanic, focused on mind and body, Meredith Osmond surveys the variety of body-part metaphors used in the lexical expression of the emotions, as well as cognitive states and their distribution among Oceanic languages (2016: 519-34). The two most prominent of these lexical resources are based on the roots * qate (most closely associated with the 'liver') and *lalom (associated with 'inside' or 'mind').

The modifying terms used in relation to these body parts comprise a relatively small repertoire_-'good', 'bad', 'heavy', 'big', 'small', 'hot' or 'hard' - to invoke feelings of happiness, sadness or anger. To which may be added, more generally, terms that describe further qualities such as 'soft', 'cool', 'firm' or 'watery', as well as aspects of motion such as 'descending', 'dropping', 'trembling' or 'quivering', together with bodily actions based on 'eating', 'swallowing' or 'holding'. 
In addition to the key body-part terms, ${ }^{*}$ qate and *lalom, other body-part terms occur: 'mouth' (POc: *qawa), 'face' (POc: *nako), 'eye' (POc: *mata), 'skin' (POc: *popo), 'head' (POc: *daba) and 'throat/voice' (POc: liqoR). ${ }^{3}$ Interestingly, the expression for 'doubt' or 'hesitation'- 'to be of two minds/heads' ( ${ }^{*}$ lalo *rua-rua) — is as common in Oceania as it is elsewhere among Austronesian speakers (Ross and Osmond 2016: 559-61). The survey also identifies where lexical substitutions have occurred. Thus, for example, *nua ('mind, inside'; POc: *nuka) has replaced *lalom in the Papuan tip languages including Dobu (see Kuehling, Chapter 7, this volume).

It is important to recognise the relational aspects of these various local conceptions of the emotions in relation to different body parts and how they are patterned differently across the Austronesian-speaking world. Among the Rotenese, the 'eyes' (mata) serve as the locus for the expression of key emotions, both positive and negative. Hence, a person's integrity as well as their 'shame' are said to be seen in their eyes. By contrast, among the Huaulu of Ceram, 'shame' as a form of ugliness is considered to be visible on the 'skin' (Valeri 2000: 405). This idea of 'skin' as the manifest expression for states of being, particularly shame, can be found among Austronesian speakers on islands on both sides of New Guinea (see Strathern 1977 for similar notions among non-Austronesians, from whom the idea may have originated). Richard Eves, in his ethnography The Magical Body, which looks at the Lelet of New Ireland, discusses the idea of 'skin' as a 'metonym for the body' that discloses 'inner states of the person to the world' where what is 'inside is made visible on the outside' (1998: 28). It follows, therefore, that 'shame is said to cover up or inhere in the skin and to be made manifest in bodily dispositions and comportments' (Eves 1998: 126). Suzanne Kuehling (Chapter 7) aptly describes the skin as the 'almost public messaging board' among the Dobu.

Given the prominence associated with the 'ear' among the Tsou, it is perhaps worth noting the pertinent general observation made by Osmond and Pawley in regard to the linguistic expression of the senses in the chapter of The Lexicon of Proto Oceanic, Volume 5, devoted to perceptions:

3 Robert Blust, in his discussion of body-part terms and their extensions (2013: 321-7), gives particular attention to metaphors based on the 'eye' (Proto-Austronesian: *maCa), but also to metaphors of the 'gall' and 'liver'. 
Comparison of a large sample of Oceanic languages shows that most verbs of sensing have remained dedicated to a single sense. For most people, sight is the primary source of objective data about the world, and evidently was treated as such by Proto Oceanic speakers. We have no examples from a sample of many dozens of languages where a verb meaning 'see' has extended its meaning to other senses, although it can carry a cognitive meaning like 'know' or 'recognise'. In contrast, *royoR 'hear' is the most semantically elastic of the sense terms. In some languages of the Solomons, Vanuatu and Polynesia, reflexes, still with the primary meaning 'hear', can be extended to 'smell', 'taste' and 'feel', although never to 'see'. (Osmond and Pawley 2016: 516)

\section{Contributions to a comparative endeavour}

This volume is an attempt to rekindle interest in the comparative study of thought and the emotions specifically in reference to Austronesianspeaking populations. Although this is rarely defined as a specific research area, the weight of ethnographic research that has already been done points to a tantalising array of patterned similarities. The agenda is open and invites further research.

As part of this agenda, the chapters in this volume offer different approaches to this research. They are ethnographic explorations based on long personal engagement with different societies over a wide stretch of the Austronesian world, from Sumatra, Borneo and Sulawesi to Rote and Timor and to Dobu in Melanesia. As a collection, these chapters cover both the western and eastern regions of the Austronesian-speaking world.

The first three chapters in this volume focus on societies in western Austronesia. Minako Sakai's paper (Chapter 2) on the Gumay of South Sumatra touches on the Malayic world of perasaan from the term rasa, which most Malay dictionaries take at least a column to attempt to explicate-a term that shades from feeling and sensation to personal experience. It also deals with the significance of dreaming (mimpi) and visions (ginaan) set within a social context that communicates across an urban-village continuum. ${ }^{4}$ Clifford Sather's paper (Chapter 3) is

4 Minako Sakai's excellent ethnography of the Gumay based on her ANU dissertation, 'The nut cannot forget its shell: Gumay identity, Islamisation and outmigration in South Sumatra', has been published in Indonesian (Kacang Tidak Lupa Kulitnya: Identitas Gumay, Islam dan Merantau di Sumatera Selatan, 2017) but not yet in English. 
a beautiful, extended disquisition on the equally elusive idea of love (rindu, kasih) among the Iban of Borneo. It is also an extension of his stunningly comprehensive monograph Seeds of Play, Words of Power (Sather 2001), which examines a large corpus of shamanistic texts that illustrate the cosmic conceptions of a lived-in spirit world. Roxana Waterson's paper (Chapter 4) offers a concerted argument for the study of empathy, whose learning she examines in children's accounts of their personal participation in the crucial rituals of the Toraja of Sulawesi. Waterson draws on decades of research among the Toraja, ethnographically encapsulated in Paths and Rivers: Sa'dan Toraja society in transformation (2009), to situate her research, while pointing to new comparative directions for the study of empathy illustrated in the recent collection of papers edited by Douglas W. Hollan and C. Jason Throop, The Anthropology of Empathy (2011). For all three of these chapters, there is a further linking theme that focuses on the shared emotions that derive from participation in key rituals.

The three chapters in this volume that deal with societies in eastern Austronesia are concerned to define a range of cognitive and emotional categories, a majority of which relate to the body and, as such, provide the underpinnings of a conception of the human person. Fox's paper (Chapter 5) examines the linguistic bases for the notion of an inner person' and the 'outward' representation of that person within Rotenese society. He draws, in particular, on the evidence of Rotenese ritual language that gives formal expression to the categorisation of thought and emotion (Fox 2014, 2016). Barbara Dix Grimes (Chapter 6) offers a similar examination of the expression of thought and emotion, among the Tetun of Timor, not as abstract 'feelings', but as 'body talk'. Her conclusion is that, among the Tetun, this body talk asserts socialemotional agency: 'as agents act, their social-emotional states are read from their bodies'. Susanne Kuehling (Chapter 7) extends these same ideas to Dobu. Her analysis, set within a comparative perspective based on fieldwork on Yap as well as on Dobu, links attitudes about posture to the expression of the 'inner' person, arguing the case for the 'Austronesian body as a site for sociality'.

All of these chapters contribute to an ethnographic understanding of a particular Austronesian-speaking population. Through such contributions, the comparative effort builds slowly, piece by piece, ethnography by ethnography. Fortunately, for the field as a whole, superb ethnographies continue to be written that cover the whole of the Austronesian-speaking world. Each of these ethnographies sets 
out to 'capture the grain of the wood' of a particular way of life and, in so doing, offers a distinctive presentation. The critical issue, for the comparative effort, is to recognise similar patterning in different contexts. An essential stricture is to continue to read and re-read this proliferation of ethnographies.

This rich ethnographic proliferation has prompted a high degree of specialisation. Developing expertise in the field of Borneo research is as daunting a task as developing expertise in the field of Oceanic research, or of Malagasy or of Moluccan research. Comparative Austronesian has, as a result, become divided by its regional competencies. For comparative purposes, a regional focus has, however, to be considered in relational perspective. Although regions may possess distinctive aspects, no region can be easily circumscribed. All regions share features of a common heritage that extends, in degrees, to other regions. Eastern Indonesia offers a particularly apt illustration of comparative complexity. As a geographic region, it comprises various distinct island subregions; it forms a linguistic transition zone within the Austronesian world (Donohue and Grimes 2008). In its more recent historical and colonial features, it has much in common with the islands of Indonesia and South-East Asia, but, in basic social structure, it shares more features with Oceania than it does with closer islands to the west (Fox 2015). Another essential stricture required for the comparative endeavour is the need to read across ethnographic regions-not simply in the attempt to recognise similarities, but rather to recognise the transformations that have given rise to differences in the Austronesian world.

\section{References}

Black, Peter W. 1985. 'Ghosts, gossip, and suicide: Meaning and action in Tobian folk psychology'. In Geoffrey M. White and John T. Kirkpatrick (eds) Person, Self, and Experience: Exploring Pacific ethnopsychologies, pp. 245-300. Berkeley, CA: University of California Press.

Blust, Robert. 2013. The Austronesian Languages. Canberra: Asia-Pacific Linguistics. Available from: hdl.handle.net/1885/10191 (accessed 28 July 2017).

Bubandt, Nils. 2015. The Empty Seashell: Witchcraft and doubt on an Indonesian island. Singapore: NUS Press. 
Donohue, Mark and Charles E. Grimes. 2008. 'Yet more on the position of the languages of eastern Indonesia and East Timor'. Oceanic Linguistics 47(1): 114-58. doi.org/10.1353/ol.0.0008.

Echols, John M. and Hassan Shadily. 1992. Kamus Indonesia Inggris [Indonesian-English Dictionary]. Jakarta: Penerbit PT Gramedia Indonesia.

Eves, Richard. 1998. The Magical Body: Power, fame and meaning in a Melanesian society. Amsterdam: Harwood Academic Publishers.

Fox, James J. 2014. Explorations in Semantic Parallelism. Canberra: ANU Press. doi.org/10.22459/ESP.07.2014.

Fox, James J. 2015. 'Eastern Indonesia in Austronesian perspective: The evidence of relational terminologies'. Archipel 90: 189-216. doi.org/10.4000/archipel.381.

Fox, James J. 2016. Master Poets, Ritual Masters: The art of oral composition among the Rotenese of eastern Indonesia. Canberra: ANU Press. doi.org/ 10.22459/MPRM.04.2016.

Geertz, Clifford. 1966. Person, time and conduct in Bali: An essay in cultural analysis. Cultural Report Series No. 14. Southeast Asian Series. New Haven, CT: Yale University. [Reprinted in Geertz, Clifford. 1973. The Interpretation of Cultures, pp. 360-411. New York: Basic Books.]

Geertz, Clifford. 1984. 'From the native's point of view: On the nature of anthropological understanding'. In Richard A. Shweder and Robert A. LeVine (eds) Culture Theory: Essays on mind, self and emotion, pp. 123-36. Cambridge: Cambridge University Press.

Geertz, Hildred. 1959. 'The vocabulary of emotion: A study of Javanese socialization'. Psychiatry 22: 225-37. doi.org/10.1080/00332747.195 9.11023175 .

Gerber, Eleanor Ruth. 1985. 'Rage and obligation: Samoan emotion in conflict'. In Geoffrey M. White and John T. Kirkpatrick (eds) Person, Self, and Experience: Exploring Pacific ethnopsychologies, pp. 121-67. Berkeley, CA: University of California Press.

Goddard, Cliff. 1996. 'The "social emotions" of Malay (Bahasa Melayu)'. Ethos 24(3): 426-64. doi.org/10.1525/eth.1996.24.3.02a00020. 
Goddard, Cliff. 2001. 'Hati: A key word in the Malay vocabulary of emotion'. In Jean Harkins and Anna Wierzbicka (eds) Emotions in Crosslinguistic Perspective, pp. 167-95. Berlin: Mouton de Gruyter. doi.org/10.1515/9783110880168.167.

Heider, Karl. 1981. Landscapes of Emotion: Mapping three cultures of emotion in Indonesia. New York: Cambridge University Press.

Heider, Karl. 2011. The Cultural Context of Emotion: Folk psychology in West Sumatra. New York: Palgrave Macmillan. doi.org/10.1057/ 9780230337596.

Hollan, Douglas W. and C. Jason Throop. 2011. The Anthropology of Empathy: Experiencing the lives of others in Pacific societies. New York: Berghahn Books.

Hollan, Douglas W. and Jane Wellenkamp. 1996. The Thread of Life: Torajan reflections on the life cycle. Honolulu: University of Hawai' $i$ Press.

Huang, Shuanfan. 2002. 'Tsou is different: A cognitive perspective on language, emotion, and body'. Cognitive Linguistics 13(2): 167-86. doi.org/10.1515/cogl.2002.013.

Ito, Karen L. 1985. 'Affective bonds: Hawaiian interrelationships of self'. In Geoffrey M. White and John T. Kirkpatrick (eds) Person, Self, and Experience: Exploring Pacific ethnopsychologies, pp. 301-27. Berkeley, CA: University of California Press.

Keeler, Ward. 1983. 'Shame and stage fright in Java'. Ethos 11(3): 152-64. doi.org/10.1525/eth.1983.11.3.02a00040.

Kirkpatrick, John T. 1985. 'Some Marquesan understandings of action and identity'. In Geoffrey M. White and John T. Kirkpatrick (eds) Person, Self, and Experience: Exploring Pacific ethnopsychologies, pp. 80-120. Berkeley, CA: University of California Press.

Lakoff, George and Mark Johnson. 1980. Metaphors We Live By. Chicago: University of Chicago Press.

Levy, Robert I. 1973. Tahitians: Mind and experience in the Society Islands. Chicago: University of Chicago Press. 
Levy, Robert I. 1983. 'Introduction: Self and emotion'. Ethos 11(3): 128-34. doi.org/10.1525/eth.1983.11.3.02a00020.

Levy, Robert I. 1984. 'Emotion, knowing and culture'. In Richard A. Shweder and Robert A. LeVine (eds) Culture Theory: Essays on Mind, Self and Emotion, pp. 214-37. Cambridge: Cambridge University Press.

Lutz, Catherine. 1982. 'The domain of emotion words on Ifaluk'. American Ethnologist 9: 113-28. doi.org/10.1525/ae.1982.9.1.02a00070.

Lutz, Catherine. 1985. 'Ethnopsychology compared to what? Explaining behaviour and consciousness among the Ifaluk'. In Geoffrey M. White and John T. Kirkpatrick (eds) Person, Self, and Experience: Exploring Pacific ethnopsychologies, pp. 35-79. Berkeley, CA: University of California Press.

Lutz, Catherine. 1988. Unnatural Emotions: Everyday sentiments on a Micronesian atoll \& their challenge to Western theory. Chicago: University of Chicago Press.

Malinowski, Bronislaw. 1922. The Argonauts of the Western Pacific. London: Routledge \& Kegan Paul.

Matisoff, James. 1986. 'Hearts and minds in South-East Asian languages and English: An essay in the comparative semantics of psychocollocations'. Cahiers de Linguistiques-Asie Orientale 15: 5-57.

Needham, Rodney. 1962. Structure and Sentiment: A test case in social anthropology. Chicago: University of Chicago Press.

Needham, Rodney. 1972. Belief, Language and Experience. Chicago: University of Chicago Press.

Osmond, Meredith. 2016. 'Body part metaphors'. In Malcolm Ross, Andrew Pawley and Meredith Osmond (eds) The Lexicon of Proto Oceanic. Volume 5: The culture and environment of ancestral Oceanic society. People-Body and mind, pp. 519-34. Canberra: Asia-Pacific Linguistics. 
Osmond, Meredith and Andrew Pawley. 2016. 'Perception'. In Malcolm Ross, Andrew Pawley and Meredith Osmond (eds) The Lexicon of Proto Oceanic. Volume 5: The culture and environment of ancestral Oceanic society. People-Body and mind, pp. 489-518. Canberra: Asia-Pacific Linguistics.

Peletz, Michael G. 1996. Reason and Passion: Representations of gender in Malay society. Berkeley, CA: University of California Press.

Rosaldo, Michelle Z. 1980. Knowledge and Passion: Ilongot notions of self and social life. Cambridge: Cambridge University Press. doi.org/ 10.1017/CBO9780511621833.

Rosaldo, Michelle Z. 1983. 'The shame of headhunters and the autonomy of self'. Ethos 11(3): 135-51. doi.org/10.1525/eth.1983. 11.3.02a00030.

Rosaldo, Michelle Z. 1984. 'Toward an anthropology of self and feeling'. In Richard A. Shweder and Robert A. LeVine (eds) Culture Theory: Essays on mind, self and emotion, pp. 137-57. Cambridge: Cambridge University Press.

Ross, Malcolm and Meredith Osmond. 2016. 'Cognition'. In Malcolm Ross, Andrew Pawley and Meredith Osmond (eds) The Lexicon of Proto Oceanic. Volume 5: The culture and environment of ancestral Oceanic society. People-Body and mind, pp. 535-66. Canberra: Asia-Pacific Linguistics.

Ross, Malcolm, Andrew Pawley and Meredith Osmond (eds). 2016. The Lexicon of Proto Oceanic. Volume 5: The culture and environment of ancestral Oceanic society. People-Body and mind. Canberra: AsiaPacific Linguistics.

Sakai, Minako. 2017. Kacang Tidak Lupa Kulitnya: Identitas Gumay, Islam dan Merantau di Sumatera Selatan [The Nut Cannot Forget its Shell: Gumay identity, Islamisation and outmigration in South Sumatra]. Jakarta: Yayasan Pustaka Obor Indonesia.

Sather, Clifford. 2001. Seeds of Play, Words of Power: An ethnographic study of Iban shamanic chants. Kuala Lumpur: Tun Jugah Foundation and Borneo Research Council. 
Senft, Gunter. 1998. 'Body and mind in the Trobriand Islands'. Ethos 26(1): 73-104. doi.org/10.1525/eth.1998.26.1.73.

Shweder, Richard A. and Robert A. LeVine (eds). 1984. Culture Theory: Essays on mind, self and emotion. Cambridge: Cambridge University Press.

Strathern, Andrew. 1977. 'Why is shame on the skin?' In John Blacking (ed.) The Anthropology of the Body, pp. 99-110. London: Academic Press.

Valeri, Valerio. 2000. The Forest of Taboos: Morality, hunting and identity among the Huaulu of the Moluccas. Madison: University of Wisconsin Press.

Waterson, Roxana. 2009. Paths and Rivers: Sa'dan Toraja society in transformation. Singapore: NUS Press. doi.org/10.1163/ 9789004253858 .

White, Geoffrey M. 1985. 'Premises and purposes in a Solomon Islands ethnopsychology'. In Geoffrey M. White and John Kirkpatrick (eds) Person, Self, and Experience: Exploring Pacific ethnopsychologies, pp. 328-66. Berkeley, CA: University of California Press.

White, Geoffrey M. and John Kirkpatrick (eds). 1985. Person, Self, and Experience: Exploring Pacific ethnopsychologies. Berkeley, CA: University of California Press. 
This text is taken from Expressions of Austronesian Thought and Emotions, edited by James J. Fox, published 2018 by ANU Press, The Australian National University, Canberra, Australia.

doi.org/10.22459/EATE.04.2018.01 